\title{
Growth and Toxicity of Protogonyaulax tamarensis in Axenic Culture
}

\author{
Hijam Tombi Singh, ${ }^{* 1, * 2}$ Yasukatsu Oshima, ${ }^{* 1}$ \\ and Takeshi YASUMOTO*1 \\ (Received February 19, 1982)
}

\begin{abstract}
One of the toxic dinofiagellates Protogonyaulax tamarensis isolated in Ofunato Bay was grown in axenic state to clarify the effects of coexistent bacteria on the toxin productivety and toxin profile of the organism. The toxicity per one cell changed according to the culture period, indicating that the variability of toxicity is associated with the physiological condition of the dinoflagellate itself, but not with the bacteria. The toxin yields in axenic culture were much higher than in unialgal culture, probably as the result of the slower growth in the former condition. A toxicity as high as $170 \times 10^{-6} \mathrm{MU} /$ cell was observed at the earliest stage of growth; this was comparable to those of the wild motile cells and cysts of the same species. The toxin profile of the cells cultured in bacteria-free condition was essentially the same as that of unialgally cultured ones.
\end{abstract}

A number of reports appeared on the toxin producing ability of Protogonyaulax (Gonyaulax) spp., the causative dinoflagellate of paralytic shellfish poisoning, but the reported value varies widely from 0.5 to $500 \times 10^{-6} \mathrm{MU} / \mathrm{cell}^{1-14)}$ This variation partly results from the fact that different species such as $\boldsymbol{P}$. catenella, $\boldsymbol{P}$. acetenella, and $\boldsymbol{P}$. tamarensis (excavata) were used in the experiments. However, several workers ${ }^{\theta, 12,13)}$ including ourselves ${ }^{15)}$ have recognized that toxicity levels vary even within the same species when different strains were tested. The change in the toxin production during the growth stage has been also known. ${ }^{6,8,14)}$ Hence analysis of factors influencing the toxin production seems to be an important task from both practical and biochemical point of view.

In our preceeding study ${ }^{18)}$ we observed that the toxicity of the cultured cells of $P$. tamarensis was far below that of the resting cysts in contrast to the report by KonAma et al. ${ }^{17)}$ who found that the toxicity of the field specimen of motile cells was nearly comparable to that of our cyst specimens. Since our previous observation was made on unialgal culture, it is conceivable that the discrepancy was brought by the coexisting bacteria in the unialgal culture.

In our present study the same strain of $P$. tamarensis was grown in both axenic and unialgal conditions and comparison was made in growth rate, toxin productivity, and toxin profile between the two cultures so that the role played by the coexisting bacteria is understood.

\section{Materials and Methods}

\section{Culture of Protogonyaulax tamarensis}

$P$. tamarensis isolate (OF-776) used in this study was obtained at Ofunato Bay, Iwate Prefecture, on July 1976 by Dr. Y. FukuYo of Kitasato University and henceforce maintained in unialgal state. ${ }^{18)}$ Axenic culture of this strain was achieved by successively washing the dinoflagellate in sterile sea water and inoculating several cells in screw capped vials containing $5 \mathrm{ml}$ of Guillard's f medium. ${ }^{19}$ ) Sterility of the cultures was checked with 3 different media; nutrient broth, ${ }^{10)}$ SST, ${ }^{10)}$ and STP, ${ }^{20)}$ each with $0.4 \%$ agar. Axenic culture thus obtained was transferred into a Elrenmeier flasks containing $60 \mathrm{ml}$ of the medium and finally grown in $3 l$ Fernbach flasks at $15^{\circ} \mathrm{C}$ under illumination with cool white fluorescent tubes for $18 \mathrm{hr}$ light period per day $(3000-5000 \mathrm{~lx})$. A portion of the culture was taken out regularly for determination of the cell density and toxin yield. In parallel to the axenic culture, a unialgal culture of the same strain was also run under the same condition.

\section{Assay Method}

*1 Faculty of Agriculture, Tohoku University, Tsutsumi-dori, Sendai, Miyagi 980, Japan (ヒジャム・トム ピ・シン・大岛泰克・安元 健：東北大学農学部).

*2 Present Address: Life Science Division, Jawaharlal Nehru University Center, Imphal, Manipur, India. 
A portion of the culture ranging from 80 to $300 \mathrm{~m} l$ depending of the cell density was centrifuged at $3000 \mathrm{rpm}$ for $10 \mathrm{~min}$. The sedimented organisms were extracted with acidified $75 \%$ ethanol as described in out previous report. ${ }^{16)}$ Mouse assay was conducted using male mice of ddY strain weighing $18-20 \mathrm{~g}$ by the standard method of A.O.A.C. using dose-urvival time relation of saxitoxin. ${ }^{21)}$ Toxicity of the organism was expressed in mouse unit (MU) per one cell.

Analysis of Toxin Composition of Axenic Culture

Approximately $1500 \mathrm{MU}$ of the toxin obtained from $6 l$ of the axenic culture was analyzed for the toxin composition by using column and thin layer chromatography and electrophoresis as described in the previous report. ${ }^{15}$ )

\section{Results}

Typical growth curves and toxicity changes in both unialagal and axenic culture are shown in Figs. 1 and 2, respectively. In the unialgal culture the organism grew rapidly with the division rate $0.19-0.33$ /day at exponential growth phase and reached the maximum density $1.9-2.2 \times 10^{4}$ cells $/ \mathrm{m} l$ about two weeks after inoculation. After reaching the stationary phase, the organism started to settle on the bottom of flasks and empty theca begun to appear in the culture followed by the gradual decrease of cell density. Both the maximum toxicity and the period to reach it varied from culture to culture.

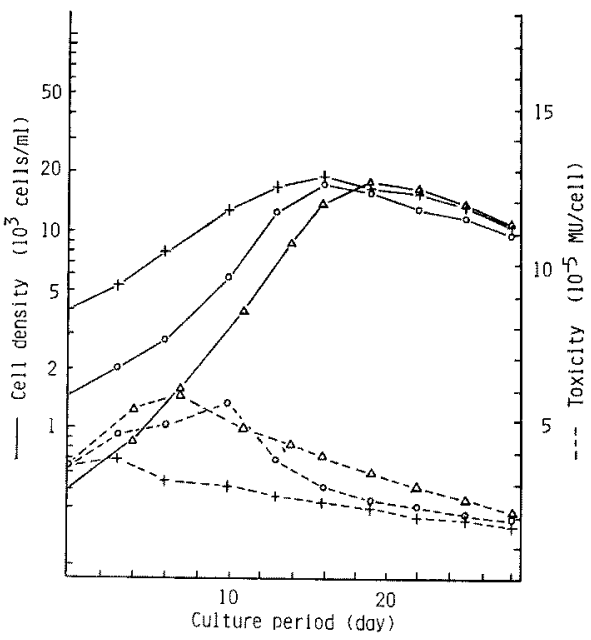

Fig. 1. Groth and toxicity of $P$. tamarensis in unialgal Culture.

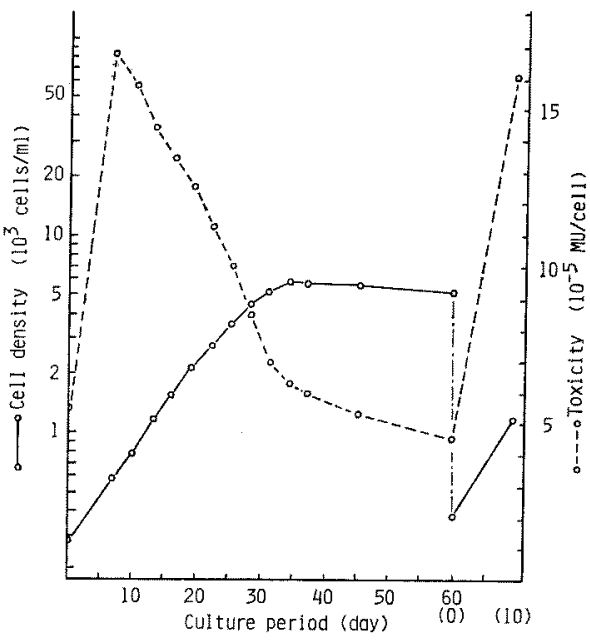

Fig. 2. Growth and toxicity of $P$. tamarensis in axenic culture.

In the axenic culture the growth rate was slower than that in the unialgal culture with the division rate $0.15 /$ day. The maximum density of the dinoflagellate was low, being only one third of that of unialgal culture, and it took nearly 40 days to reach the stationary growth phase. On the contrary, the toxin yield per cell was found high especially in the early stage of culture. A toxic value as high as $170 \times 10^{-6} \mathrm{MU} /$ cell was observed 7 days after inoculation, when the cell density reached the level sufficient for the first collection of the cells for toxicity test. After that period the toxicity decreased gradually in accordance with the increase of cell density but a significantly high toxicity level of $45 \times 10^{-6} \mathrm{MU} / \mathrm{cell}$ was still maintained even after 60 days. This value is 2 times that of the maximum toxicity attained in the unialgal culture. The pattern of toxicity change was observed repeatedly when the organism was inoculated into new culture medium.

The cells cultured in axenic condition contained 5 components, gonyautoxins I-IV and neosaxitoxin, in essentially the same propotions as those of the toxins produced in the unialgal state. ${ }^{15,18)}$

\section{Discussion}

In the axenic culture, the toxicity of the organism expressed in terms of MU/cell changed during the culture period following the same pattern repeatedly. This result implies such variation is a phenomenon associated with the physiological condition of the cell itself and is 
irrelevant to the coexistent bacteria. Thus, when comparison of toxin producibility of different species or strains is planned, a special cuation is required in chosing the right moment for collecting the cells for toxicity test.

The retarded growth and the low maximum cell density in the axenic culture suggested the defficiency of some nutrients in the medium and the possible compensation for such substances by bacteria in the unialgal culture. On the other hand, the high toxin content in the axenically propagated cells may be related to their slow growth. The high toxicity of cells at young stage or in a dilute culture observed by other investigators $^{8,10)}$ also supports this view. On the other hand, the low toxin production by the organism in the unialgal culture is likely to be the result of the promoted growth but not result of the supression on toxin production by the bacterial metabolites.

It should be mentioned that the maximum toxicity of the organism in the axenic culture was much higher than that of the unialgally cultured one and was comparable to that of the wild specimen (ca. $200 \times 10^{-3} \mathrm{MU} / \mathrm{cell}$ ), ${ }^{17}$ ) which in turn was close to that of the resting cysts. ${ }^{18)}$ This result is in contradiction with the statement of DALE et al. ${ }^{10\rangle}$ that resting cysts are more toxic than motile cells by a magnitude of ten. The discrepancy may have resulted from the fact that their comparison was made between different strains or that the toxicity of the motile cells was measured in the cultural condition in which toxin production was inferior to that of the naturally occurring cells.

Analysis of the toxin profile of the axenically cultured cells confirmed that the coexistence of bacteria affected only the toxin yield but not the toxin composition.

\section{Acknowledgement}

The authors are grateful to Dr. Y. FuKuYo of Kitasato University for the donation of $P$. tamarensis (OF-776) strain. This investigation was supported by a Grant-in-Aid for Scientific Research of the Ministry of Education, Science and Culture, Japan.

\section{References}

1) H. Sommer, W. F. Whedon, C. A. Kofold, and R. STOHLER: Arch. Pathol., 24, 537-559 (1937).

2) J. M. Burke, J. Marchisotto, J. J. A. McLaUGhlin, and L. Provasoll: Ann. N.Y. Acad. Sci., 90, 832-834 (1960).

3) A. Prakash: J. Fish. Res. Board Can, 20, 983996 (1960).

4) E. J. Schantz and H. W. Magnusson: $J$. Protozool., 11, 239-242 (1964).

5) A. Prakash and F. J. R. Taylor: J. Fish. Res. Board Can., 23, 1265-1270 (1966).

6) A. Prakash: J. Fish. Res. Board Can., 24, 1589 1606 (1967).

7) N. H. Proctor, S. L. Chan, and A. J. Trevor: Toxicon, 13, 1-9 (1975).

8) A. W. White and L. Marand: J. Fish. Res. Board Can., 36, 397-402 (1978).

9) R. J. Schmidt, V. D. Gooch, A. R. Loeblich, III, and J. W. Hastings: J. Phycol., 14, 5-9 (1978).

10) B. Dale, C. M. Yentsch, and J.W. Hurst: Science, 201, 1223-1225 (1978).

11) H. A. Bates, R. Kostriken, and H. Rapoport: Toxicon, 16, 595-611 (1978).

12) R. J. Schmidt and A. R. Loeblich, III: J. Mar. Biol. Ass. U.K., 59, 479-487 (1979).

13) M. I. Alam, C. P. Hsu, and Y. Shmizu: $J$. Phycol., 15, 106-110 (1979).

14) Y. Oshima and T. Yasumoto: in "Toxic Dinoflagellate Blooms" (ed. by D. L. TAYLOR and H. H. SEliger), Elsevier North-Holland, New York, 1979, pp. 377-380.

15) Y. Oshima, T. Hayakawa, M. Hashimoto, Y, Kotaki, and T. YasUmoto: Bull. Japan. Soc. Sci. Fish., 48, 851-854 (1982).

16) Y. Oshima, H. T. Singh, and T. Yasumoto: Bull. Japan. Soc. Sci. Fish., 48, 1303-1305 (1982).

17) M. Kodama, Y. Fukuyo, T. Ogata, T. Igarashi, H. Kamiya, and F. MatsuUra: Bull. Japan. Soc. Sci. Fish., 48, 567-571 (1982).

18) R. R. Guillard and H. RYTHER: Can. J, Microbiol., 8, 229-239 (1962).

19) R. W. Hosaaw and J. R. Rosowsky: in "Hand Book of Phycological Methods. Culture Methods and Growth Measurement" (ed. by J. R. SteIN), Cambridge University Press, Cambridge, 1973, pp. 53-68.

20) L. Provasoli, J. J. A. McLaughlin, and M. R. Droop: Arch. Mikrobiol., 25, 392-428 (1957).

21) W. Horwitz (ed.): Official Methods of Analysis of the Association of Official Analytical Chemists, 13th ed., A.O.A.C., Washington, D.C., 1980, pp. 298-299. 